\title{
Introduction to the symposium on post-Keynesian and feminist economics
}

Irene Van Staveren and Colin Danby

Published as: van Staveren, Irene, and Colin Danby, 'Introduction to the Symposium on Post-Keynesian and Feminist Economics', Cambridge Journal of Economics 34 (6), 2010, pp. 1105-1107.

The papers in this symposium treat feminist economics as a source of foundational insight and critique. They extend a dialogue between the feminist and post-Keynesian literatures on questions of theory, method, epistemology, and ontology.

Dialogues across literatures raise questions of delimitation. Efforts to axiomatize postKeynesianism are contentious; feminist economics is even harder to typify given the range of feminist theories and variety of relevant economics paradigms. These questions are discussed in Siobhan Austen and Therese Jefferson's paper for this symposium. To borrow Hamouda and Harcourt (1988)'s term, we approach both post-Keynesianism and feminism as capacious portmanteaus, and look for particular, well-formed ideas within each large tradition that might be helpful in the other.

Kaleckian feminism is the richest current channel of communication between the two literatures. Lourdes Benería, Elissa Braunstein, Nilüfer Çağatay, Diane Elson, Gerald Epstein, Maria Floro, Caren Grown, James Heinz, Stephanie Seguino, and other writers have used a range of insights from feminist economics and sociology to extend structural macroeconomics. This literature draws stylized facts from a range of household and workplace studies and engages an impressive range of empirical data. 
It was our hope to include in this symposium a recent paper in this tradition, but the editors of this Journal did not share our views about its relevance to this project. Nonetheless we hope that this symposium will be read as part of the larger project these scholars have pioneered.

Austen and Jefferson's paper begins the symposium, and explicates the pluralist basis on which it is premised. The authors start from the disparate reactions to Critical Realism in the two literatures: post-Keynesians have been largely untroubled by ontological realism, and by the epistemological privilege that this ontology bestows on social scientists. On the other hand many feminists, steeped in critiques of epistemic authority, recoil from what they see as naïve positivism and the marginalization of other perspectives and means of knowing. They are therefore more cautious and tend to emphasize an epistemological stance in which the situatedness of the enquirer is both recognized and challenged. Austen and Jefferson extend a heterodox literature on pluralism as they outline a basis for discussion that recognizes, and does not always seek to close, significant differences.

In this spirit Irene van Staveren's paper highlights three concepts from each tradition that might inform work in the other. From the feminist side she proposes gender, the household, and unpaid work/caring. A social concept of gender might inform a postKeynesian alternative to neoclassical rational economic man. Feminist research on agency and power can extend post-Keynesian theories of the household past consumption to the decisions on savings, investment, and production made within it. Motivations for unpaid work and caring may, the author proposes, be regarded as the 
mirror-image of the animal spirits Keynes saw driving investment decisions. On the other side of the exchange, van Staveren singles out post-Keynesian work on uncertainty, market power, and endogenous dynamics. Keynes' distinction between risk and uncertainty would clarify the role of unpaid work and care as more concerned with confronting uncertainty. Post-Keynesian analyses of market power could extend a largely micro feminist analysis of labour markets to the macroeconomy. Finally, post-Keynesian theory could help feminists endogenize variables like labour demand and money supply. Van Staveren draws links to the Kaleckian feminist literature discussed above.

S. Charusheela's paper uses a powerful insight from feminist and queer theory, about state-imposed heteronormativity, to provide a social foundation for a post-Keynesian theory of consumption. Answering Coddington's critique that fundamental uncertainty would destabilize the consumption function and unhinge macroeconomic policy, she suggests that gender performances stabilize consumption, as people buy in order to produce respectable and state-sanctioned "households." Drawing on case studies in which the ability of specific groups to make appropriate households has been contested, she surfaces a history of state regulation and enforcement, especially in cities, that conditions consumption as it enforces standards and patterns of residence and use of space. One result of this analysis is that "household" ceases to be a natural, taken-for-granted category and comes into view as an object of state regulation and policing. This paper problematizes men as much as it does women: a gender analysis is not simply a matter of adding women, but of asking what is at stake in gender performance. 
Denaturalizing a category like "household" opens the question of what work has to be done so that "households" come into existence and function. While Charusheela's paper discusses the ways states condition households, Colin Danby's paper looks from beneath, as it were, at the skeins of relationships that compose households, kin networks, and other institutions within which care services are provided. Such relationships are made and maintained by the individuals involved, but are also fragile, incomplete, and exhibit patterns of exclusion. Such an intermediate level of personalized tie is also present in parts of Post-Keynesian theory: there is a direct ontological link between the two literatures. On the other hand, this level of relationship cannot be assimilated to the rules-and-roles conception of "structure" prominent among Critical Realist thinkers: larger structures may enable, shape, and constrain these networks of personalized ties, but they are not the same thing. This is an argument that starts directly from social ontology, although it does have implications for the capacities for knowledge of individuals within society, something that the care literature has usefully explored.

Danby's paper returns us to the larger basis for discussion developed by Austen and Jefferson. The goal of exchange is not for one school to encapsulate the other. Rather, we seek concepts and critiques that can open and extend particular areas of investigation. Concepts taken for granted or considered unproblematic within one tradition may be richly critiqued in the other, and new resonances may emerge when methods and assumptions are compared. 
We hope that these papers encourage further work that takes advantage of the width and depth of the potential connections, and critiques that can be made across the two traditions. For example, many studies that have been done in post-Keynesian economics that take gender into account limit themselves to the analysis of gendered job segmentation, ignoring other possible integrated ways of analysing women's labour market position vis-à-vis men's. We thank Tony Lawson for his enthusiasm for this project, his suggestions for possible authors, and his substantial comments on the papers' topics and directions. We also thank CJE editors and referees for their attention to this project and efforts to make it possible.

Hamouda, O. F. and Harcourt. G. C. 1988. Post Keynesianism: From Criticism to Coherence, Bulletin of Economic Research, vol. 40, no. 1, 1-33 